\title{
The density and biomass of mesozooplankton and ichthyoplankton in the Negro and the Amazon Rivers during the rainy season: the ecological importance of the confluence boundary
}

Ryota Nakajima ${ }^{\text {Corresp., }}{ }^{1}$ ， Elvis V Rimachi ${ }^{2}$ ， Edinaldo N Santos-Silva ${ }^{2}$, Laura SF Calixto ${ }^{2}$, Rosseval G Leite $^{2}$, Adi Khen ${ }^{1}$, Tetsuo Yamane ${ }^{3}$, Anthony I Mazeroll ${ }^{4,5}$, Jomber C Inuma ${ }^{6}$, Erika YK Utumi ${ }^{7}$, Akira Tanaka

${ }^{1}$ Scripps Institution of Oceanography, University of California San Diego, La Jolla, California, United States

2 National Institute of Amazonian Research (INPA), Manaus, Amazonas, Brazil

3 Biotechnology Laboratory, Amazonas State University (UEA), Manaus, Amazonas, Brazil

${ }^{4}$ Soka University of America, Aliso Viejo, California, United States

${ }^{5}$ Amazon Research Center for Ornamental Fishes, Iquitos, Peru

${ }^{6}$ Centro de Projetos e Estudos Ambientais do Amazonas (CEPEAM), Manaus, Amazonas, Brazil

7 Instituto Água Floresta e Vida, Manaus, Amazonas, Brazil

Corresponding Author: Ryota Nakajima

Email address: rnakajima@ucsd.edu

The boundary zone between two different hydrological regimes is often a biologically enriched environment with distinct planktonic communities. In the center of the Amazon River basin, muddy white water of the Amazon River meets with black water of the Negro River, creating a conspicuous visible boundary spanning over $10 \mathrm{~km}$ along the Amazon River. Here, we tested the hypothesis that the confluence boundary between the white and black water rivers concentrates prey and is used as a feeding habitat for consumers by investigating the density, biomass and distribution of mesozooplankton and ichthyoplankton communities across the two rivers during rainy season. Our results show that mean mesozooplankton density $\left(2,730\right.$ inds. $\left.\mathrm{m}^{-3}\right)$ and biomass $\left(4.8 \mathrm{mg} \mathrm{m}^{-3}\right)$ were higher in the black-water river compared to the white-water river (959 inds. $\mathrm{m}^{-3} ; 2.4 \mathrm{mg}$ $\left.\mathrm{m}^{-3}\right)$; however an exceptionally high mesozooplankton density was not observed in the confluence boundary. Nonetheless we found the highest density of ichthyoplankton in the confluence boundary ( 9.7 inds. $\mathrm{m}^{-3}$ ), being up to 9 -fold higher than in adjacent rivers. The confluence between white and black waters is sandwiched by both environments with low (white water) and high (black water) zooplankton concentrations and by both environments with low (white water) and high (black water) predation pressures for fish larvae, and may function as a boundary layer that offers benefits of both high prey concentrations and low predation risk. This forms a plausible explanation for the high density of ichthyoplankton in the confluence zone of black and white water rivers. 
1 The density and biomass of mesozooplankton and ichthyoplankton in the Negro and the

2 Amazon Rivers during the rainy season: the ecological importance of the confluence

3 boundary

4

5 Ryota Nakajima ${ }^{1}$, Elvis V. Rimachi ${ }^{2}$, Edinaldo N. Santos-Silva ${ }^{2}$, Laura S. F. Calixto ${ }^{2}$, Rosseval

6 G. Leite ${ }^{2}$, Adi Khen ${ }^{1}$, Tetsuo Yamane ${ }^{3}$, Anthony I. Mazeroll ${ }^{4,5}$, Jomber C. Inuma ${ }^{6}$, Erika Y.K.

7 Utumi $^{7}$, Akira Tanaka ${ }^{7}$

9 'Scripps Institution of Oceanography, University of California San Diego, La Jolla, CA, USA

$10{ }^{2}$ National Institute of Amazonian Research (INPA), Manaus, Amazonas, Brazil

11 33iotechnology Laboratory, Amazonas State University (UEA), Manaus, Amazonas, Brazil

$12{ }^{4}$ Soka University of America, Aliso Viejo, CA, USA

$13{ }^{5}$ Amazon Research Center for Ornamental Fishes, Iquitos, Peru

$14{ }^{6}$ Centro de Projetos e Estudos Ambientais do Amazonas (CEPEAM), Manaus, Amazonas, Brazil

$15{ }^{7}$ Instituto Água Floresta e Vida, Manaus, Amazonas, Brazil

17 Correspondence Author: Ryota Nakajima (rnakajima@ucsd.edu) 


\section{Abstract}

23 The boundary zone between two different hydrological regimes is often a biologically enriched

24 environment with distinct planktonic communities. In the center of the Amazon River basin,

25 muddy white water of the Amazon River meets with black water of the Negro River, creating a

26 conspicuous visible boundary spanning over $10 \mathrm{~km}$ along the Amazon River. Here, we tested the

27 hypothesis that the confluence boundary between the white and black water rivers concentrates

28 prey and is used as a feeding habitat for consumers by investigating the density, biomass and

29 distribution of mesozooplankton and ichthyoplankton communities across the two rivers during

30 rainy season. Our results show that mean mesozooplankton density $\left(2,730\right.$ inds. $\left.\mathrm{m}^{-3}\right)$ and biomass

$31\left(4.8 \mathrm{mg} \mathrm{m}^{-3}\right)$ were higher in the black-water river compared to the white-water river (959 inds. $\mathrm{m}^{-}$

32 3; $2.4 \mathrm{mg} \mathrm{m}^{-3}$ ); however an exceptionally high mesozooplankton density was not observed in the

33 confluence boundary. Nonetheless we found the highest density of ichthyoplankton in the

34 confluence boundary $\left(9.7\right.$ inds. $\left.\mathrm{m}^{-3}\right)$, being up to 9-fold higher than in adjacent rivers. The

35 confluence between white and black waters is sandwiched by both environments with low (white

36 water) and high (black water) zooplankton concentrations and by both environments with low

37 (white water) and high (black water) predation pressures for fish larvae, and may function as a

38 boundary layer that offers benefits of both high prey concentrations and low predation risk. This

39 forms a plausible explanation for the high density of ichthyoplankton in the confluence zone of

40 black and white water rivers. 


\section{Introduction}

The region where two different hydrological regimes meet is characterized by strong physical and biological processes (Walkusz et al. 2010; Bolotov, Tsvetkov \& Krylov, 2012). The boundary zone between two densities of waters is generally enriched in both dissolved and particulate organic matters as well as distinct planktonic communities as a result of their accumulation at this interface (Hill \& Wheeler, 2002; Walkusz et al., 2010). Extensive research on oceanic fronts between coastal water and river plumes has shown that the boundary zone can lead to increased primary productivity (Franks 1992), mechanically concentrating zooplankton (Epstein and Beardsley 2001; Morgan et al. 2005), and attracting tertiary consumers (Grimes and Kingsford 1996). Thus, the boundary zone is important for local ecosystem functioning. world and has the highest level of discharge, contributing with ca. $20 \%$ to the total global continental water discharge into the oceans (Sioli 1984). In the center of the Amazon basin, muddy white water of the Amazon River (locally named Rio Solimões) meets with black water of the Negro River, one of the largest tributaries, creating a conspicuous visible boundary spanning over $10 \mathrm{~km}$ along the Amazon River (Fig. 1). The black water of the Negro River is derived from the high concentration of humic substances, while the white water of the Amazon River is derived from highly suspended inorganic materials (Sioli 1984; Furch and Junk 1997;

62 Junk et al. 2015). The water properties of the white and black waters are different in terms of many parameters such as flow speed, conductivity, turbidity, $\mathrm{pH}$, water temperature, nutrient 
64 concentrations, and dissolved and particulate organic matter concentrations (Laraque et al. 1999;

65 Moreira-Turcq et al. 2003; Leite et al. 2006; Filizola et al. 2009; Laraque et al. 2009; Franzinelli

66 2011; Röpke et al. 2016). Due to these differences, the black and white water rivers are not

67 completely mixed until over $100 \mathrm{~km}$ beyond the confluence (Laraque, Guyot \& Filizola, 2009). Zooplankton are one of the central players in the Amazon River ecosystem, acting as a

69 trophic link between primary producers and higher trophic levels including planktivorous fish

70 (Araujo-Lima et al. 1986; Hawlitschek et al. 2013). The conspicuous boundary between black

71 and white water rivers may be ecologically important as it may act as a mechanical aggregator of

72 zooplankton, and contribute to the subsequent attraction of consumers such as fish larvae.

73 However, the density and biomass of zooplankton at the confluence remains unclear from a

74 quantitative perspective. To date, most studies on zooplankton in this region have been

75 conducted in the floodplain lakes associated with large black and white water rivers (Brandorff

76 1978; Robertson and Hardy 1984; Trevisan and Forsberg 2007; Ghidini and Santos-Silva 2011),

77 but studies from large rivers are scarce (Robertson and Hardy 1984) and there is no comparison

78 of zooplankton between black and white water rivers. Similarly, previous studies investigated

79 zooplankton in the floodplain lakes of mixed waters from black and white water rivers (Trevisan

80 and Forsberg 2007; Caraballo et al. 2016), yet very little is known about the boundary interface

81 between white and black water rivers.

82 Here, we tested the hypothesis that the confluence boundary between the white water

83 of the Amazon River and the black water of the Negro River concentrates potential planktonic

84 prey for consumers. For this purpose we examined 1) the density, biomass and composition of 
85 mesozooplankton in black and white water rivers and 2) the density and composition of

86 mesozooplankton and ichthyoplankton at the confluence and how much they differ in respect to

87 the black and white water rivers.

88

89 Materials \& Methods

90

91 Study sites

The study was conducted in the center of the Amazon basin where the white water of the Amazon River (locally named Rio Solimões) and the black water of the Negro River (locally

94 named Rio Negro) merge in Manaus, Brazil (Fig. 1). All experiments and preparation of samples

95 were carried out using the facilities of Centro de Projetos e Estudos Ambientais do Amazonas

96 (CEPEAM) on the banks of the Negro River. The sampling of mesozooplankton was conducted

97 at five sites across the rivers: the bank (St. 1) (S0307'36.35";W5953'10.25") and center (St. 2)

98 (S0307'29.89";W5953'30.92") of the Amazon River, the confluence (St. 3)

99 (S0307'29.64"; W5953'55.10"), and the center (St. 4) (S0307'13.43";W5954'05.19") and bank

100 (St. 5) (S0306'57.97";W5954'17.74") of the Negro River (Fig. 1). The bottom of the Amazon

101 River is characterized by muddy and sandy sediments, while the river bottom of the Negro River

102 by hard bedrocks (Junk et al. 2015). The water depths at the five sites were $11 \mathrm{~m}$ (St. 1), $72 \mathrm{~m}$ (St.

103 2), $44 \mathrm{~m}$ (St. 3), $62 \mathrm{~m}$ (St. 4) and $6 \mathrm{~m}$ (St. 5), which were measured by a measuring rope with a $10420 \mathrm{~kg}$ weight. 
106

107

108

110

111

112

113

114

115

116

117

118

120

121

122

123

124

125

126

Sample collection

We collected mesozooplankton (including ichthyoplankton) from March 8-12, 2012 during the rising water period (rainy season). In total, 6 samplings were conducted at each sampling site. Mesozooplankton and ichthyoplankton were sampled by pooling three vertical tows of a plankton net (mesh size, $180-\mu \mathrm{m}$; diameter, $30 \mathrm{~cm}$; length, $100 \mathrm{~cm}$ ) equipped with a flowmeter (Rigo) from $10 \mathrm{~m}$ depth to the surface, except at St. 5 where towing was done from 5 $m$ depth. Due to a large amount of sand and detrital particles such as plant debris, especially in the white water, the net was washed after every towing in order to reduce net clogging. The pooled samples were immediately brought back to the field laboratory within $30 \mathrm{~min}$, and fixed with buffered formalin to a final concentration of $5 \%$ for subsequent microscopic observation. Prior to the plankton collection, transparency was measured using a Secchi disc and water temperature was measured with a mercury thermometer at each site. In addition, surface water was sampled by a $10 \mathrm{~L}$ bucket at three sites (St. 1, 3 and 5) for the analyses of chlorophyll- $a$ (chl-a), particulate organic carbon (POC) and nitrogen (PON) concentrations. The collected water $(10 \mathrm{~L})$ from each of the three sites was pre-filtered through a $180-\mu \mathrm{m}$ mesh screen to remove zooplankton and the water samples were brought back to the laboratory along with the plankton samples.

\section{Sample analysis}

For chlorophyll analysis, duplicate subsamples (50-100 mL each from bucket) were filtered onto $\mathrm{GF} / \mathrm{F}$ filters $\left(25 \mathrm{~mm}\right.$, Whatman), then immersed in $90 \%$ acetone and stored at $5^{\circ} \mathrm{C}$ for 
$12724 \mathrm{~h}$. After centrifugation at $3000 \mathrm{rpm}$ for $5 \mathrm{~min}$, the concentrations of chl- $a$ were determined using

128 a spectrometer (Shimadzu, UV mini 1240) according to the equation of Ritchie (2006). For POC

129 and PON analysis, duplicate subsamples (100-200 mL from bucket) were filtered onto pre-

130 combusted $\left(500^{\circ} \mathrm{C}, 4 \mathrm{~h}\right) \mathrm{GF} / \mathrm{F}$ filters $(25 \mathrm{~mm}$, Whatman $)$, and then dried for $24 \mathrm{~h}$ at $60^{\circ} \mathrm{C}$ and

131 stored in a desiccator until analysis. The concentration of POC and PON was measured using a CN

132 analyzer (Fisons EA 1108 CHNS/O).

133 Mesozooplankton were identified to the lowest possible taxonomic level and counted

134 under a dissecting microscope (Leica MZ9.5). Upon observation, large debris (e.g. wood and plant

135 debris) was removed from the samples as much as possible, and then rose bengal was added to

136 facilitate the separation of organisms from suspended matter. Large zooplankton and/or rare

137 species (e.g. larval insects and calanoid copepods) and ichthyoplankton were first counted and

138 sorted out, then the remaining was split (1/2-1/16), from which all zooplankton were characterized

139 and enumerated. At least 300 zooplankton were enumerated in each sample. Copepods and

140 cladocerans were identified to species level and insect larvae and ichthyoplankton to family level

141 whenever possible.

142 The body length of copepods, cladocerans and insect larvae was measured using an

143 eyepiece micrometer. The length measurements of zooplankton individuals were converted to dry

144 weight $(D W, \mathrm{mg})$ using previously reported length-weight regression equations (Table 1). The

145 biomass $\left(B, \mathrm{mg} \mathrm{m}^{-3}\right)$ of a given taxonomic group was estimated based on its density $\left(A\right.$, inds. $\left.\mathrm{m}^{-3}\right)$

146 and individual dry weight: $B=A \times D W$. Reported length-weight regressions of some species that 
147 occur at the sampling site were not available, but we used regressions according to similar genera

148 or shapes. Regressions established in tropical waters were also used when possible.

149

150 Statistical analysis

151 The difference in the environmental factors and density and biomass of

152 mesozooplankton and ichthyoplankton between the Amazon River (mean of St. 1-2) and the

153 Negro River (mean of St. 4-5) was determined using two-sided Student's $t$-test. The difference in

154 the density of ichthyoplankton between different sites was determined using one-way ANOVA

155 and then differences among means were analyzed using Tukey-Kramer multiple comparison

156 tests. A difference at $P<0.05$ was considered significant.

157 Spatial similarities of mesozooplankton assemblage structure were graphically

158 depicted using non-metric multidimensional scaling (MDS) and group average clustering was

159 carried out. The similarity matrix obtained from the density values was calculated by the Bray-

160 Curtis index (Bray and Curtis 1957) with square-root transformed data. To test for spatial

161 variation in community density, analysis of similarities (ANOSIM) was then undertaken (Clarke

162 and Warwick 1994). All multivariate analyses were conducted with the software PRIMER v. 6

163 (Plymouth Marine Laboratory).

164

165 Results

166

167 Environmental factors and the structure of the confluence 

consistently distinct for white and black water rivers (Table 2). The values in the confluence in

170 general were in the middle between black and white water rivers. The average (mean \pm SD)

171 surface water temperature in black water $\left(28.1 \pm 0.1{ }^{\circ} \mathrm{C}\right.$, mean of St. 4-5) was significantly

172 higher by $0.61 \pm 0.59^{\circ} \mathrm{C}$ than that in white water $\left(27.5 \pm 0.8^{\circ} \mathrm{C}\right.$, mean of St. $\left.1-2\right)$. Transparency

173 (Secchi depth) was significantly lower in white water $(0.28 \pm 0.04 \mathrm{~m}$, mean of St. 1-2) than black

174 water $(1.16 \pm 0.12 \mathrm{~m}$, mean of St. 4-5) (Table 2).

The chl- $a$ concentrations were significantly higher in white water, being 1.9-fold

176 higher than in black water (Table 2). POC and PON concentrations in white and black rivers also

177 significantly differed, being 2.8-2.9-folds higher in black water river (Table 2). C/N ratio was 178 comparable between black and white water rivers (3.8-3.9), but lower in the confluence (2.8).

Mesozooplankton density and biomass

181 The highest density $\left(2,817 \pm 1,162\right.$ inds. $\mathrm{m}^{-3}$, mean $\left.\pm \mathrm{SD}\right)$ and biomass $(5.14 \pm 2.55 \mathrm{mg}$

$182 \mathrm{~m}^{-3}$ ) of mesozooplankton were observed at the center of the Negro River (St. 4), while the lowest 183 density $\left(577 \pm 345\right.$ inds. $\left.\mathrm{m}^{-3}\right)$ and biomass $\left(1.30 \pm 0.46 \mathrm{mg} \mathrm{m}^{-3}\right)$ were observed at the center (St.

184 2) of the Amazon River (Fig. 2a, b). The mesozooplankton density and biomass in the black 185 water river $\left(2,730 \pm 1,129\right.$ inds. $\mathrm{m}^{-3} ; 4.82 \pm 2.22 \mathrm{mg} \mathrm{m}^{-3}$, mean of St. 4-5) significantly exceeded 186 those of white water river $\left(959 \pm 463\right.$ inds. $\mathrm{m}^{-3} ; 2.36 \pm 1.33 \mathrm{mg} \mathrm{m}^{-3}$, mean of St. $\left.1-2\right)$ by 2.8 and 187 2.0-fold higher, respectively (Table 3). At the confluence (St. 3), the mesozooplankton density $188\left(2,060 \pm 1,269\right.$ inds. $\left.\mathrm{m}^{-3}\right)$ showed intermediate values between black and white water rivers, 
189 while the biomass $\left(4.70 \pm 3.28 \mathrm{mg} \mathrm{C} \mathrm{m}^{-3}\right)$ was comparable to that in the black water river. The

190 mesozooplankton density and biomass in the confluence showed the highest value among the

191 sampling sites two times out of a total of 6 sampling times.

192

Cladocerans were the most dominant group in terms of density, contributing with

$66.2 \%-82.2 \%$ to the total mesozooplankton density at all sites, followed by copepods (19.7-

194

$41.7 \%$ ) and insect larvae $(0.1-0.6 \%)$ (Fig. 2a). On the contrary, copepods were the most

important in terms of biomass, contributing with $64.0-79.1 \%$ to the total mesozooplankton biomass, followed by cladocerans (13.4-20.9\%) and insect larvae (6.5-17.4\%) (Fig. 2b).

The density and biomass of cladocerans in the black water river were significantly

higher $\left(1,962 \pm 875\right.$ inds. $\mathrm{m}^{-3} ; 0.92 \pm 0.42 \mathrm{mg} \mathrm{m}^{-3}$, mean of St. $\left.4-5\right)$ than those of the white water river $\left(621 \pm 330\right.$ inds. $\mathrm{m}^{-3} ; 0.37 \pm 0.19 \mathrm{mg} \mathrm{m}^{-3}$, mean of St. 1-2) (Tables 3, 4). In total, 26 species of cladocerans were observed (Table S1), among which Diaphanosoma polyspina was the most dominant taxa at all sites, contributing with $33.4 \%-65.5 \%$ to the total cladoceran density and $51.2 \%-80.3 \%$ of the biomass (Fig. 2c,d). Among the dominant cladocerans that comprised $1 \%$ or 203 more of total cladoceran density at all sites, Bosmina hagmanni, B. longirostris and B. deitersi showed higher density and biomass in black water than in white water (Fig. 2c,d). In contrast, those of Moina minuta were higher in white water than in black water.

207 river $\left(763 \pm 530\right.$ inds. $\mathrm{m}^{-3} ; 3.37 \pm 1.76 \mathrm{mg} \mathrm{m}^{-3}$, mean of St. $\left.4-5\right)$ than in the white water river 208 (331 \pm 164 inds. $\mathrm{m}^{-3} ; 1.77 \pm 1.22 \mathrm{mg} \mathrm{m}^{-3}$, mean of St. 1-2) (Tables 3, 4). In total, 25 species of 209 copepods were observed (Table S2), among which (excluding copepodites) Oithona amazonica 
210 was the most dominant taxa in terms of density at all sites, contributing with $9.0 \%-40.6 \%$ to the

211 total copepod density, while Dactylodiaptomus pearsei was the most important in terms of

212 biomass (34.6-58.5\%) (Fig. 2e,f). The highest density of $O$. amazonica was observed at the

213 center (St. 4$)$ of black water river $\left(388 \pm 566\right.$ inds. $\left.\mathrm{m}^{-3}\right)$, followed by the confluence $(349 \pm 405$

214 inds. $\left.\mathrm{m}^{-3}\right)$.

215 Although there was no significant difference in the density of insect larvae between the

216 white $\left(3.8 \pm 2.4\right.$ inds. $\mathrm{m}^{-3}$, mean of St. $\left.1-2\right)$ and black water rivers $\left(5.0 \pm 3.1\right.$ inds. $\mathrm{m}^{-3}$, mean of St.

217 4-5), the biomass of insect larvae was significantly higher in the black water river $(0.53 \pm 0.39$

$\left.218 \mathrm{mg} \mathrm{m}^{-3}\right)$ than in the white water river $\left(0.22 \pm 0.13 \mathrm{mg} \mathrm{m}^{-3}\right)($ Tables 3,4$)$. The density of insect

219 larvae was highest in the bank (St. 5) of black water river, followed by the confluence (St. 3) and

220 the bank (St. 1) of white water river (Fig. 2g). Chaoboridae (diptera) was numerically abundant

221 in the black water river, while chironomidae (diptera) and coleoptera were dominant in the white

222 water river (Fig. 2g, Table S3). The biomass of insect larvae was the highest in the bank of the

223 black water river (St. 5) decreasing toward the bank (St. 1) of the white water river (Fig. 2h).

224

225

Ordination of the mesozooplankton community

The MDS ordination plot and group-average clustering showed that mesozooplankton communities in the black water river were clearly separated from those in the white water river

(Fig. 3). The result of ANOSIM test showed that the community structure between black and from the confluence were in between black and white water communities. 
232 Ichthyoplankton density and composition

233

The density of larval fish (ichthyoplankton) was significantly higher in the white water

234 river $\left(3.2 \pm 3.1\right.$ inds. $\mathrm{m}^{-3}$, mean of St. $\left.1-2\right)$ than in the black water river $\left(1.2 \pm 1.3\right.$ inds. $\mathrm{m}^{-3}$, mean

235 of St. 4-5) ( $t$-test, $P=0.045)$. The density of larval fish in the confluence (St. 3$)(9.7 \pm 2.5$ inds

$236 \mathrm{~m}^{-3}$ ) was significantly and 2.1-8.8 times higher than in all the other 4 sites $($ Tukey-Kramer, $\mathrm{df}=$

237 29, $P<0.01$ ) (Fig. 4). Characiformes were the most dominant group in the confluence,

238 contributing with $47.2 \%$ to the total larval fish density, followed by Pimelodidae (siluriformes,

$23934.5 \%$ ). The larval fish density at the bank of white water river (St. 1) was the next abundant (4.6

$240 \pm 3.7$ inds $\mathrm{m}^{-3}$ ). Auchenipteridae (siluriformes) were only sampled at the banks of both white (St.

241 1) and black water rivers (St. 5), while clupeiformes were only observed in the center of the

242 white water river (St. 2).

243

244 Discussion

245

246

Water properties of the two rivers

This study describes the density and biomass of mesozooplankton and ichthyoplankton across the Negro River (black water) and the Amazon River (white water) in the center of the Amazon basin to elucidate the distributional differences between the two rivers and their confluence zone, which were not previously well-described quantitatively. The water properties 
252 water rivers, while chlorophyll and particulate organic matter concentrations were higher in 253 white water rivers. water, which is congruent with previous studies reporting higher temperature by $1^{\circ} \mathrm{C}$ in the Negro River (Franzinelli 2011). The higher water temperature in the Negro River may result

257 from its darker color and slower current speed compared to the Amazon River (0.1-0.3 $\mathrm{m} \mathrm{s}^{-1} \mathrm{vs}$. 1.0-1.3 $\mathrm{m} \mathrm{s}^{-1}$ ) (Moreira-Turcq et al. 2003; Filizola et al. 2009; Franzinelli 2011). that in the black water river $\left(2.0 \mu \mathrm{g} \mathrm{L}^{-1}\right)$ in this study. Although concentrations are much

261 different between lakes and rivers, a similar pattern was previously reported in floodplain lakes, 262 where surface water chl- $a$ concentration was higher in lakes associated with the Amazon River 263 (white water, 50-80 $\mu \mathrm{g} \mathrm{l}^{-1}$ ) than in lakes adjacent to the Negro River (black water, 10-20 $\mu \mathrm{g}^{-1}$ ) 264 (Fisher and Parsley 1979; Trevisan and Forsberg 2007). Higher chl- $a$ concentration in white water lakes is due to the higher concentrations of inorganic nutrients derived from the Amazon River (Trevisan and Forsberg 2007). However, in the Amazon River, the production of phytoplankton is not likely because of poor light penetration due to high turbidity (euphotic depth: ca. $0.3 \mathrm{~m}$ ), where the mixing depth was probably always down to the bottom due to 269 turbulence associated with the strong current, making respiration higher than photosynthesis

270 (Fisher and Parsley 1979). Therefore, the higher chlorophyll concentration in the Amazon River 271 probably results from the input of more productive environments such as the adjacent lakes 272 (Fisher and Parsley 1979). 


\section{Mesozooplankton difference between black and white water rivers}

275

As the MDS and ANOSIM analyses clearly indicated, the present study revealed that

276

the compositions of mesozooplankton assemblages differ between the white water of the

277

Amazon River and black water of the Negro River. We also found a higher density of

278

mesozooplankton communities in black water river compared to white water river. The density

279

of zooplankton in tropical large rivers depend largely on the supply from adjacent lentic sources

280

(standing water bodies) connected to the river such as channel and floodplain habitats (Rzoska

281

1978; Saunders and Lewis 1988a; Saunders and Lewis 1989; Basu and Pick 1996; Reckendorfer

282

et al. 1999; Górski et al. 2013). The zooplankton sampling period in this study corresponds to the

283

rising water period (March), where rising riverine water starts to wash out ambient zooplankton

284 from associated lentic sources into the rivers (Saunders and Lewis 1988a; Saunders and Lewis

1988b; Saunders and Lewis 1989). Assuming that adjacent lentic areas (e.g., floodplain lakes)

are a major source of zooplankton in river systems in this study, there may have been more

zooplankton transport from stagnant water bodies connected to the Negro River (black water)

288

compared to those of the Amazon River (white water). However, there are fewer lakes in the

Negro River floodplain than in the floodplains of white water rivers because of the lower

hydrodynamics (Junk et al. 2015). Previous studies from floodplain lakes in the center of the

291 Amazon basin reported that the density of mesozooplankton (cladocerans and copepods) was 2-

29225 fold higher in black water lakes associated with the Negro River than in white water lakes 
293 during rising-high water periods (Feb-June) (Brandorff 1978; Hardy 1980), which might explain

294 the higher mesozooplankton density in the black water river in this study. density (Basu and Pick 1996). Considering that the flow speed of the Amazon River (Rio

Solimões) exceeds $1.0 \mathrm{~m} \mathrm{~s}^{-1}$ (Filizola et al. 2009), reproduction of zooplankton may be

300 impossible in this white water river. Large amounts of inorganic suspended particles in white

301 water river may also negatively influence zooplankton density in this system (McCabe and

302 O’Brien 1983; Kirk and Gilbert 1990; Junk and Robertson 1997). Indeed, zooplankton density in

303 the white water river was higher in the bank than at the center, suggesting that adjacent lentic

304 sources are the primary source of zooplankton in this white river system. On the contrary,

305 mesozooplankton in the Negro River showed higher density in the center of the river than in the

306 bank, implying that zooplankton reproduction occurs in this slower current of black water river

307 (0.1-0.3 $\left.\mathrm{m} \mathrm{s}^{-1}\right)$ (Moreira-Turcq et al. 2003; Franzinelli 2011). During the low-water periods, most

308 floodplain lakes are isolated from the active river channel, which leads to a lower supply of

309 zooplankton to the large rivers (Saunders and Lewis 1989). The density of zooplankton in

310 tropical large rivers during low-water period might be primarily determined by the reproduction

311 of zooplankton in the rivers. In summary, the higher supply of zooplankton from adjacent lentic

312 water bodies (such as floodplain lakes) and/or possible reproduction could help to explain why 
313 mesozooplankton density was higher in the black water river compared to the white water river

314 at the rising water period.

315

316 Mesozooplankton and ichthyoplankton in the confluence

317 As previously examined in oceanic frontal boundaries between river plumes and adjacent

318 marine waters (Morgan et al. 2005; Walkusz et al. 2010), convergent flow at the boundary between

319 distinct water masses functions to concentrate planktonic organisms. However, an exceptionally

320 high zooplankton number, as often seen in oceanic fronts (Morgan et al. 2005), was not observed

321 in the confluence boundary in this study. The highest average density of mesozooplankton was

322 observed in the center of black water river (the Negro River), though zooplankton biomass was

323 similar between the confluence and the black water river. Unlike oceanic fronts, where riverine

324 freshwater plumes stand still facing the coastal marine water, which enhances the mechanical

325 concentration of zooplankton (Morgan et al. 2005), the black and white water rivers in the present

326 study flow down together (but without mixing), probably making the zooplankton concentration

327 less distinguished in the boundary zone. However it should be noted that the mesozooplankton

328 density and biomass in the confluence was far higher than that in white water river, and the density

329 and biomass of mesozooplankton in the confluence sometimes exceeded those in the Negro River.

330 Zooplankton density can be higher due to accumulation at the areas where the velocity of the water

331 current drops in the confluence of rivers (Bolotov, Tsvetkov \& Krylov, 2012). The different

332 current speeds between the Amazon River $\left(\sim 0.3 \mathrm{~m} \mathrm{~s}^{-1}\right)$ and the Negro River $\left(1.0 \sim \mathrm{m} \mathrm{s}^{-1}\right)$ (Moreira- 
333 Turcq et al., 2003) could be a trigger for the episodic higher density of mesozooplankton in the

334 confluence.

336 ichthyoplankton (usually a net with a larger mouth and mesh opening is used), thus our net may

337 have misrepresented the number and species richness of fish larvae. Yet, we found significantly

338 higher density of fish larvae in the confluence throughout the study period, supporting the

339 hypothesis that the confluence between white and black water rivers functions as an ecological

340 concentrator of ichthyoplankton (Morgan et al. 2005).

342 boundary zone. Previous studies revealed that turbidity affects predation risk through less

343 predation risk in turbid water because turbidity reduces the distance at which predator-prey

344 interactions occur (Abrahams and Kattenfeld 1997; Ranåker et al. 2014). Turbulence is also one of

345 the factors affecting predation risk through lower risk in more turbulent habitats (Weissburg and

346 Zimmer-Faust 1993). In black water rivers, potentially higher predation risks for larval fish would

347 be expected given that larvae can be more easily seen by predators due to fewer suspended solids

348 (De Lima and Araujo-Lima 2004). On the contrary, white waters with high suspended solids are

349 considered to be safer places for larval fish because of lower transparency and higher turbulence,

350 which may act as refuge from predators (Weissburg and Zimmer-Faust 1993; De Lima and Araujo-

351 Lima 2004). Therefore the confluence zone can be a boundary interface between high and low

352 predation pressures for fish larvae. From the perspective of food availability (at least for

353 zooplanktivorous fish), the confluence between white and black waters is sandwiched by both 
354 environments with low and high food concentrations. Fish larvae may find more prey in black

355 water river, yet fish larvae density was the lowest in the Negro River, suggesting higher predation

356 pressure in black water river even in a food-rich environment. Therefore, the confluence zone

357 between black and white water rivers may function as a boundary layer that has benefits from both

358 low predation risk and high food concentrations for fish larvae. Similar observation was previously

359 reported on the surface of a freshwater marsh where a great density of small fish was found at a

360 site adjacent to the shallow depositional bank compared to a site adjacent to the deeper erosional

361 bank, due to greater prey availability and less predator pressure at the site adjacent to the

362 depositional habitat (McIvor and Odum 1988). In summary, the combined effects of food

363 availability and predator avoidance form a plausible explanation for the high density of

364 ichthyoplankton in the confluence zone of black and white water rivers. The lower $\mathrm{C} / \mathrm{N}$ ratio of

365 POM found in the confluence compared to the adjacent rivers may be the result of higher

366 heterotrophic activity in this boundary zone since the $\mathrm{C} / \mathrm{N}$ ratio of carnivorous fish feces is

367 generally very low (Smriga et al. 2010).

368

369 Conclusion

We found that mesozooplankton density and biomass were higher in the black water of

372 the Negro River compared to the muddy white water of the Amazon River, probably due to a

373 higher supply of zooplankton from lentic waters adjacent to the Negro River and/or reproduction.

374 An exceptionally high mesozooplankton density was not observed in the confluence boundary 
375 between the two rivers; nonetheless we found that the confluence zone acts as an aggregator of

376 ichthyoplankton. The confluence boundary between black and white water rivers may function as

377 a boundary layer that offers benefits of both high food (zooplankton) concentrations from black

378 water river and low predation risk from white water river. This forms a plausible explanation for

379 the high density of ichthyoplankton in the confluence zone.

\section{Acknowledgments}

382

383

The authors thank F. Mariano, J. Pablo T.C.A., V.H. Estefes and E.S. Hase for field

384

assistance; D.R. Freitas (Centro de Biotecnologia da Amazonia) for help in chlorophyll

measurements; and three anonymous reviewers for helpful comments on this manuscript. The

first author thanks S. Sato and T. Toda (Soka University) for help in visa application and

providing a plankton net; and J. Hashimoto (Nagaseya, an aquarium shop in Tokyo) for providing a motivation to conduct this research.

\section{References}

Abrahams M V, Kattenfeld MG (1997) The role of turbidity as a constraint on predator-prey interactions in aquatic environments. Behav Ecol Sociobiol 40:169-174.

394 Araujo-Lima C, Forsberg BR, Victoria R, Martinelli L (1986) Energy sources for detritivorous

395 fishes in the Amazon. Science(Washington) 234:1256-1257.

396 Basu BK, Pick FR (1996) Factors regulating phytoplankton and zooplankton biomass in temperate rivers. Limnol Oceanogr 41:1572-1577.

398 Bertani I, Ferrari I, Rossetti G (2012) Role of intra-community biotic interactions in structuring 
riverine zooplankton under low-flow, summer conditions. J Plankton Res 34:308-320.

400

401

402

403

404

405

406

407

408

409

410

411

412

413

414

415

416

417

418

419

420

421

422

423

424

425

426

427

428

429

430

Bolotov SE, Tsvetkov AI, Krylov A V (2012) Zooplankton in the zones of confluence of unregulated rivers. Inl Water Biol 5:184-191.

Brandorff G-O (1978) Preliminary comparison of the crustacean plankton of a white water and a black water lake in Central Amazonia. Verhandlungen des Int Verein Limnol 20:1198-1202.

Bray J, Curtis J (1957) An ordination of the upland forest communities of southern Wisconsin. Ecol Monogr 27:325-349.

Caraballo P, Forsberg B, Leite R (2016) Abundance and isotopic composition of planktonic microcrustaceans in a central Amazon floodplain lake: implications for the trophic dynamics of the plankton community. Caldasia 38:149-164.

Clarke KR, Warwick RM (1994) Similarity-based testing for community pattern: the two-way layout with no replication. Mar Biol 118:167-176.

De Lima ÁC, Araujo-Lima CARM (2004) The distributions of larval and juvenile fishes in Amazonian rivers of different nutrient status. Freshw Biol 49:787-800.

Duncan WP, Fernandes MN (2010) Physicochemical characterization of the white, black, and clearwater rivers of the Amazon Basin and its implications on the distribution of freshwater stingrays (Chondrichthyes, Potamotrygonidae). Panam J Aquat Sci 5:454-464.

Epstein AW, Beardsley RC (2001) Flow-induced aggregation of plankton at a front: a 2-D Eulerian model study. Deep Sea Res Part II Top Stud Oceanogr 48:395-418.

Filizola N, Spínola N, Arruda W, Seyler F, Calmant S, Silva J (2009) The Rio Negro and Rio Solimões confluence point-hydrometric observations during the 2006/2007 cycle. River, Coast Estuar Morphodynamics RCEM 1003-1006.

Fisher TR, Parsley PE (1979) Amazon lakes: Water storage and nutrient stripping by algae. Limnol Oceanogr 24:547-553.

Franks PJS (1992) Sink or swim: Accumulation of biomass at fronts. Mar Ecol Prog Ser Oldend $82: 1-12$.

Franzinelli E (2011) Morphological characteristics of the Negro and Solimoes rivers confluence. Rev Bras Geociências 41:587-596.

Furch K, Junk WJ (1997) Physicochemical conditions in the floodplains. In: The Central Amazon Floodplain. Springer, pp 69-108

Ghidini AR, Santos-Silva EN (2011) Composition, species richness and patterns of nycthemeral vertical distribution of planktonic cladocereans in a black water Amazonian lake. Nauplius 
19:109-122.

432 Górski K, Collier KJ, Duggan IC, Taylor CM, Hamilton DP (2013) Connectivity and complexity 433 of floodplain habitats govern zooplankton dynamics in a large temperate river system.

$434 \quad$ Freshw Biol 58:1458-1470.

435 Grimes CB, Kingsford MJ (1996) How do riverine plumes of different sizes influence fish 436 larvae: do they enhance recruitment? Mar Freshw Res 47:191-208.

437 Hardy ER (1980) Composição do zooplâncton em cinco lagos da Amazônia Central. Acta Amaz $438 \quad 10: 577-609$.

439 Hawlitschek O, Yamamoto KC, Neto FGMRC (2013) Diet composition of fish assemblage of $440 \quad$ Lake Tupe, Amazonas, Brazil. Rev Colomb Cienc Anim 5:313-326.

441 Hill JK, Wheeler PA (2002) Organic carbon and nitrogen in the northern California current 442 system: comparison of offshore, river plume, and coastally upwelled waters. Prog Oceanogr $443 \quad 53: 369-387$.

444 Junk WJ, Robertson BA (1997) Aquatic invertebrates. In: The Central Amazon Floodplain. $445 \quad$ Springer, pp 279-298

446 Junk WJ, Wittmann F, Schöngart J, Piedade MTF (2015) A classification of the major habitats of 447 Amazonian black-water river floodplains and a comparison with their white-water counterparts. Wetl Ecol Manag 23:677-693.

Keppeler EC (2003) Comparative study of the zooplankton composition of two lacustrine ecosystems in southwestern Amazonia. Acta Sci Biol Sci 467-477.

451 Kirk KL, Gilbert JJ (1990) Suspended clay and the population dynamics of planktonic rotifers 452 and cladocerans. Ecology 71:1741-1755.

453 Laraque A, Guyot JL, Filizola N (2009) Mixing processes in the Amazon River at the confluences of the Negro and Solimoes Rivers, Encontro das Aguas, Manaus, Brazil. Hydrol Process 23:3131.

Laraque A, Guyot JL, Seyler P, Filizola NP (1999) Dynamique hydrologique et géochimique de la rencontre des rios Solimões et Negro dans le bassin de l'Amazone. In: Proceedings of the 459 Conference on Hydrological and Geochemical Processes in Large Scale River Basins. pp 18

460 Leite RG, Silva JVV da, Freitas CE (2006) Abundância e distribuição das larvas de peixes no 461 Lago Catalão e no encontro dos rios Solimões e Negro, Amazonas, Brasil. Acta Amaz 462 36:557-562. 
463 McCabe GD, O’Brien WJ (1983) The effects of suspended silt on feeding and reproduction of 464 Daphnia pulex. Am Midl Nat 110:324-337.

465 McIvor CC, Odum WE (1988) Food, predation risk, and microhabitat selection in a marsh fish 466 assemblage. Ecology 69:1341-1351.

467 Moreira-Turcq PF, Seyler P, Guyot JL, Etcheber H (2003) Characteristics of organic matter in 468 the mixing zone of the Rio Negro and Rio Solimoes of the Amazon River. Hydrol Process 469 17:1393-1404.

Morgan CA, De Robertis A, Zabel RW (2005) Columbia River plume fronts. I. Hydrography, zooplankton distribution, and community composition. Mar Ecol Prog Ser 299:19-31.

Ranåker L, Persson J, Jönsson M, Nilssson PA, Brönmark C (2014) Piscivore-prey fish interactions: mechanisms behind diurnal patterns in prey selectivity in brown and clear water. PLoS One 9:e102002.

Reckendorfer W, Keckeis H, Winkler G, Schiemer F (1999) Zooplankton abundance in the River Danube, Austria: the significance of inshore retention. Freshw Biol 41:583-591.

Ritchie RJ (2006) Consistent sets of spectrophotometric chlorophyll equations for acetone, methanol and ethanol solvents. Photosynth Res 89:27-41.

Robertson BA, Hardy ER (1984) Zooplankton of Amazonian lakes and rivers. In: The Amazon. Springer, pp 337-352

Röpke CP, Amadio SA, Winemiller KO, Zuanon J (2016) Seasonal dynamics of the fish assemblage in a floodplain lake at the confluence of the Negro and Amazon Rivers. J Fish Biol 89:194-212.

Rzoska J (1978) On the Nature of Rivers. In: Junk W (ed) The Hague. p 67

Saint-Paul U, Zuanon J, Correa MAV, Garcí a M, Fabré NN (2000) Fish communities in central Amazonian white-and blackwater floodplains. Environ Biol Fishes 57:235-250.

Saunders JFI, Lewis WMJ (1988a) Zooplankton abundance and transport in a tropical whitewater river. Hydrobiologia 162:147-155.

Saunders JFI, Lewis WMJ (1989) Zooplankton abundance in the lower Orinoco River, Venezuela. Limnol Oceanogr 34:397-409.

Saunders JFI, Lewis WMJ (1988b) Zooplankton abundance in the Caura River, Venezuela. 492 Biotropica 20:206-214.

493 Sioli H (1984) The Amazon and its main affluents: hydrography, morphology of the river 494 courses, and river types. In: The Amazon: Limnology and landscape-Ecology of a Mighty 
495 Tropical River and its Basin. Springer, pp 127-165

496 Smriga S, Sandin SA, Azam F (2010) Abundance, diversity, and activity of microbial

497 assemblages associated with coral reef fish guts and feces. FEMS Microbiol Ecol 73:31-42.

498 Trevisan G V, Forsberg BR (2007) Relationships among nitrogen and total phosphorus, algal

499 biomass and zooplankton density in the central Amazonia lakes. Hydrobiologia 586:357500365.

501 Walkusz W, Paulić JE, Kwaśniewski S, Williams WJ, Wong S, Papst MH (2010) Distribution, 502 diversity and biomass of summer zooplankton from the coastal Canadian Beaufort Sea. 503 Polar Biol 33:321-335.

504 Weissburg MJ, Zimmer-Faust RK (1993) Life and Death in Moving Fluids: Hydrodynamic 505 Effects on Chemosensory-Mediated Predation. Ecology 74:1428-1443. 


\section{Figure 1}

Location of the study sites

(A) the Amazon Basin in South America. (B) the Amazon River (locally named Rio Solimões) and the Negro River in the center of the Amazon basin. (C) sampling sites across the two rivers: bank (St. 1) and center (St. 2) of the Amazon River, the confluence (St. 3), and center (St. 4) and bank (St. 5) of the Negro River. (D) the confluence. 


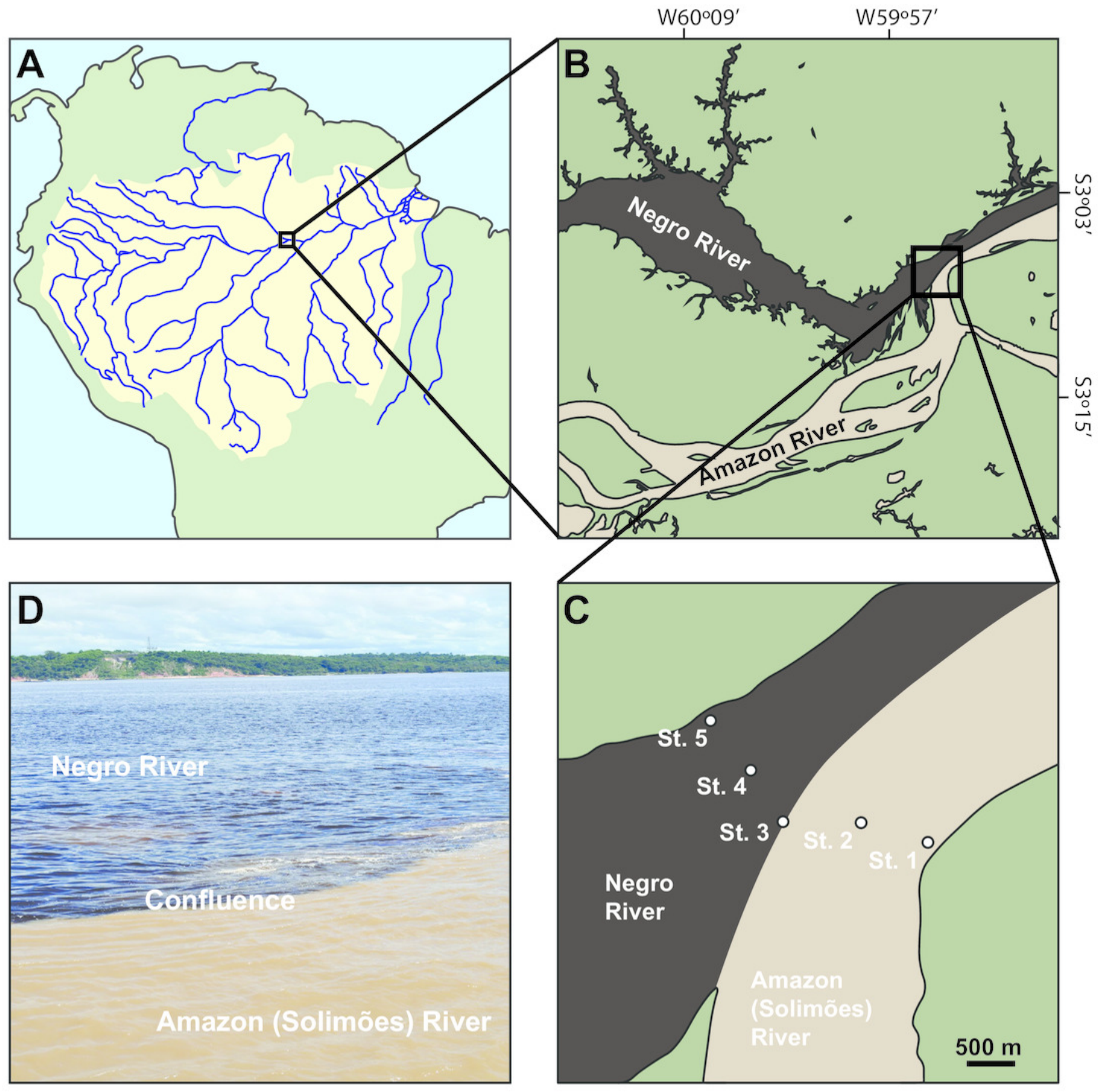




\section{Figure 2}

Spatial variations in density and biomass of mesozooplankton

Average (mean $\pm S D$ ) density and biomass of $(A, B)$ total mesozooplankton, $(C, D)$

cladocerans, (E,F) copepods, and $(\mathrm{G}, \mathrm{H})$ insect larvae in the Amazon River (St. 1-2), the confluence (St. 3), and the Negro River (St. 4-5) in the center of the Amazon basin. Error bars represent standard deviation (SD) of abundance or biomass for 6 replicate measurements. Each legend category indicates the proportion of each taxon per mean. 

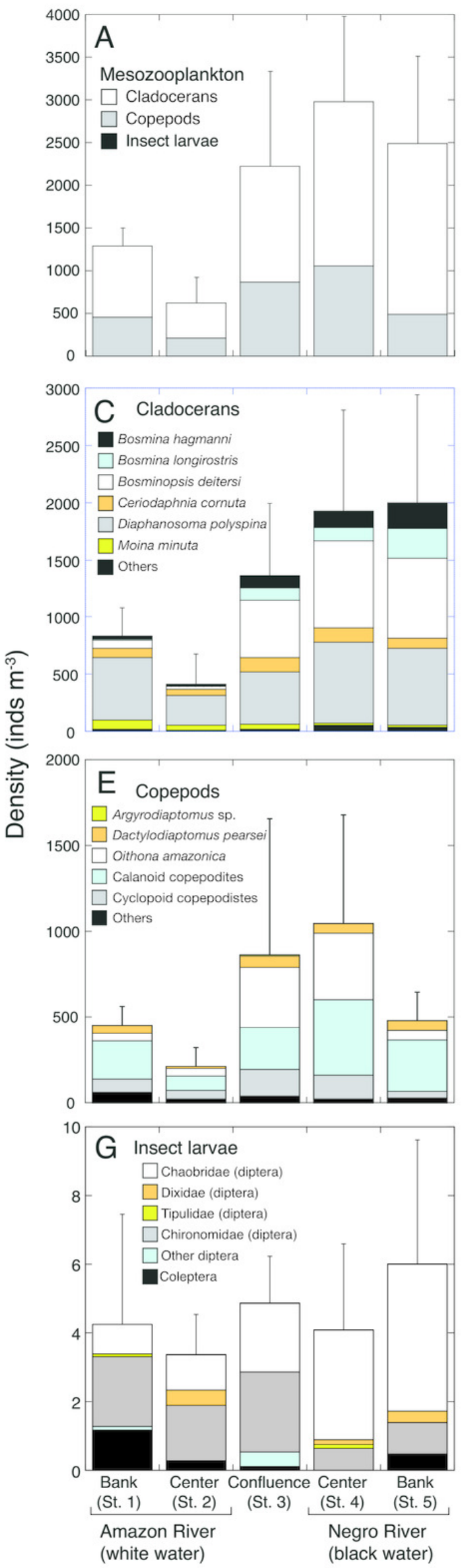
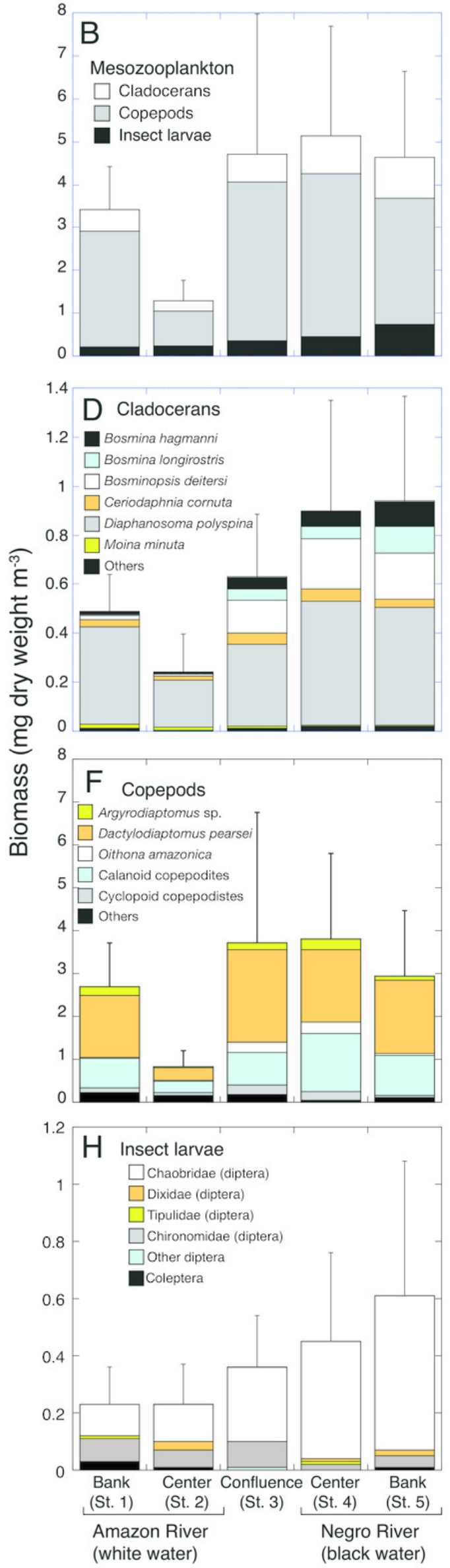


\section{Figure 3}

Non-metric multidimensional scaling (MDS) plots

MDS plots showing similarity of mesozooplankton community in different sites (the Amazon

River; the Negro River; the confluence). Bray-Curtis similarities were calculated based on the square-root of abundance. The legends above each symbol indicate sampling station (st1-5), and date of sampling (8-12 March 2012).

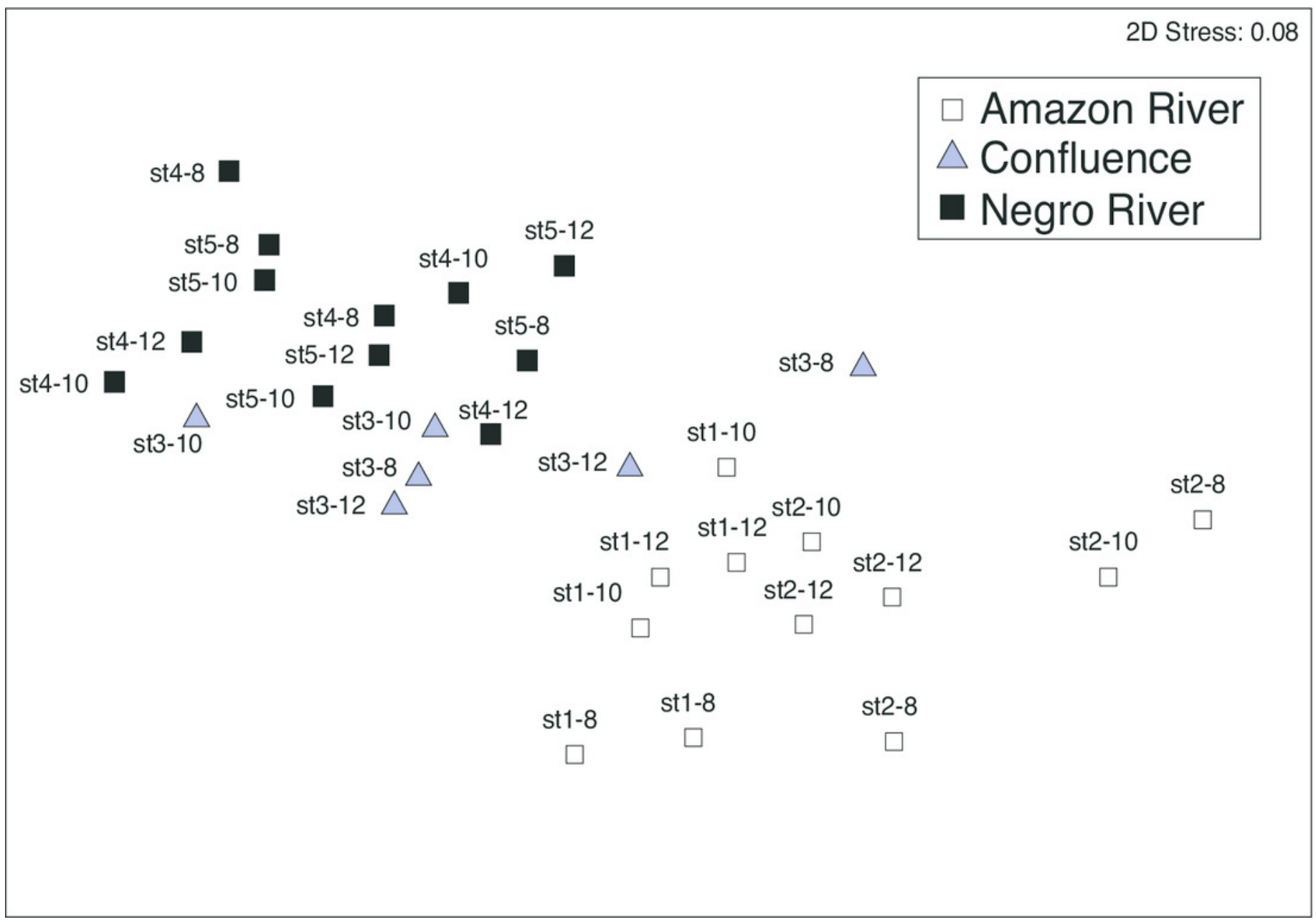




\section{Figure 4}

Spatial variation in abundance of ichthyoplankton

Average (mean $\pm \mathrm{SD}$ ) density of ichthyoplankton community in the surface water of the Amazon River (St. 1-2), the confluence (St. 3), and the Negro River (St. 4-5). Error bars represent standard deviation (SD) of ichthyoplankton abundance for 6 replicate measurements. Each legend category indicates the proportion of each taxon per mean. 


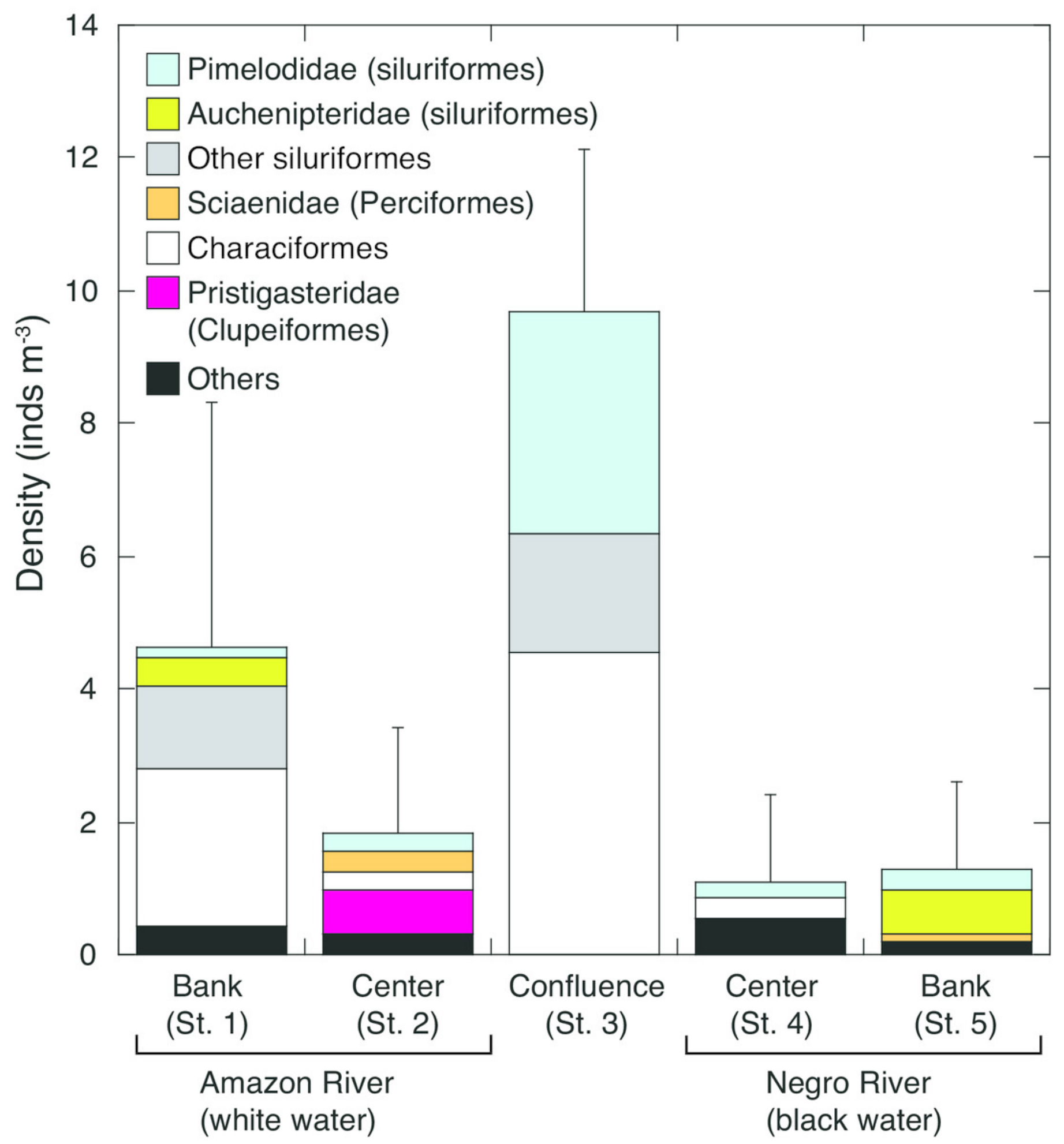




\section{Table $\mathbf{1}$ (on next page)}

Length-weight regression equations

Length-weight regression equations used for biomass calculations of different mesozooplankton taxa. DW, dry weight; L, body length; In, natural logarithm $\left(\log _{\mathrm{e}}\right)$. 


\begin{tabular}{|c|c|c|}
\hline Taxonomic group & Equation & Source \\
\hline \multicolumn{3}{|l|}{ Cladocerans } \\
\hline Bosmina sp. & $\ln \mathrm{DW}(\mu \mathrm{g})=2.68 \ln \mathrm{L}(\mathrm{mm})+2.479$ & Maia-Barbosa \& Bozelli (2005) \\
\hline Bosminopsis sp. & $\ln \mathrm{DW}(\mu \mathrm{g})=2.221 \ln \mathrm{L}(\mathrm{mm})+1.808$ & Maia-Barbosa \& Bozelli (2005) \\
\hline Ceriodaphnia cornuta & $\ln \mathrm{DW}(\mu \mathrm{g})=1.888 \ln \mathrm{L}(\mathrm{mm})+1.442$ & Maia-Barbosa \& Bozelli (2005) \\
\hline Chydorus sp. & $\ln \mathrm{DW}(\mu \mathrm{g})=3.93 \ln \mathrm{L}(\mathrm{mm})+4.493$ & Dumont, Van de Velde \& Dumont (1975) \\
\hline Daphnia gessneri & $\ln \mathrm{DW}(\mu \mathrm{g})=3.22 \ln \mathrm{L}(\mathrm{mm})+1.169$ & Azevedo \& Dias (2012) \\
\hline Diaphanosomoa birgei & $\ln \mathrm{DW}(\mu \mathrm{g})=1.738 \ln \mathrm{L}(\mathrm{mm})+1.653$ & Maia-Barbosa \& Bozelli (2005) \\
\hline Diaphanosoma sp. & $\ln \mathrm{DW}(\mu \mathrm{g})=2.22 \ln \mathrm{L}(\mathrm{mm})+1.140$ & Azevedo \& Dias (2012) \\
\hline Macrothrix sp. & $\ln \mathrm{DW}(\mu \mathrm{g})=3.177 \ln \mathrm{L}(\mathrm{mm})+2.850$ & Azevedo \& Dias (2012) \\
\hline Moina sp. & $\ln \mathrm{DW}(\mu \mathrm{g})=1.549 \ln \mathrm{L}(\mathrm{mm})+0.149$ & Maia-Barbosa \& Bozelli (2005) \\
\hline Other cladocerans & $\ln \mathrm{DW}(\mu \mathrm{g})=2.653 \ln \mathrm{L}(\mathrm{mm})+1.751$ & Bottrell et al. (1976) \\
\hline \multicolumn{3}{|l|}{ Copepods } \\
\hline Argyrodiaptomus sp. & $\ln \mathrm{DW}(\mu \mathrm{g})=2.560 \ln \mathrm{L}(\mathrm{mm})+2.440$ & Azevedo \& Dias (2012) \\
\hline Notodiaptomus sp. & $\ln \mathrm{DW}(\mu \mathrm{g})=2.160 \ln \mathrm{L}(\mathrm{mm})+2.290$ & Azevedo \& Dias (2012) \\
\hline Other calanoids & $\ln \mathrm{DW}(\mu \mathrm{g})=3.150 \ln \mathrm{L}(\mathrm{mm})+2.470$ & Azevedo \& Dias (2012) \\
\hline Eucyclops sp. & $\ln \mathrm{DW}(\mu \mathrm{g})=2.40 \ln \mathrm{L}(\mathrm{mm})+1.953$ & Bottrell et al. (1976) \\
\hline Mesocyclops sp. & $\ln \mathrm{DW}(\mu \mathrm{g})=2.556 \ln \mathrm{L}(\mathrm{mm})+1.211$ & Shumka et al. (2008) \\
\hline Thermocyclops decipiens & $\ln \mathrm{DW}(\mu \mathrm{g})=3.244 \ln \mathrm{L}(\mathrm{mm})+1.570$ & Azevedo \& Dias (2012) \\
\hline Thermocyclops minutus & $\ln \mathrm{DW}(\mu \mathrm{g})=2.770 \ln \mathrm{L}(\mathrm{mm})+1.340$ & Azevedo \& Dias (2012) \\
\hline Other cyclopoids & $\ln \mathrm{DW}(\mu \mathrm{g})=2.40 \ln \mathrm{L}(\mathrm{mm})+1.953$ & Bottrell et al. (1976) \\
\hline All nauplii & $\ln \mathrm{DW}(\mu \mathrm{g})=2.40 \ln \mathrm{L}(\mathrm{mm})+1.953$ & Bottrell et al. (1976) \\
\hline \multicolumn{3}{|l|}{ Insect larvae } \\
\hline Chaoboridae (diptera) & $\ln \mathrm{DW}(\mathrm{mg})=2.692 \ln \mathrm{L}(\mathrm{mm})-5.992$ & Benke et al. (1999) \\
\hline Tipulidae (diptera) & $\ln \mathrm{DW}(\mathrm{mg})=2.681 \ln \mathrm{L}(\mathrm{mm})-5.843$ & Benke et al. (1999) \\
\hline Chironomidae (diptera) & $\ln \mathrm{DW}(\mathrm{mg})=2.618 \ln \mathrm{L}(\mathrm{mm})-6.320$ & Benke et al. (1999) \\
\hline Other diptera & $\ln \mathrm{DW}(\mathrm{mg})=2.692 \ln \mathrm{L}(\mathrm{mm})-5.992$ & Benke et al. (1999) \\
\hline Coleoptera & $\ln \mathrm{DW}(\mathrm{mg})=2.910 \ln \mathrm{L}(\mathrm{mm})-4.867$ & Benke et al. (1999) \\
\hline
\end{tabular}




\section{Table 2 (on next page)}

Hydrological data

Average (mean \pm SD) water temperature (WT), transparency (Secchi depth), chlorophyll-a (chl-a), particulate organic carbon (POC) and nitrogen (PON) in the Amazon River (St. 1-2), the confluence (St. 3), and the Negro River (St. 4-5) in the center of the Amazon basin.. P values indicate the differences in the values between the Amazon Rivers and the Negro Rivers, tested by Student's $t$-test. $P$ values for WT and transparency were from the comparison between the average of St. 1-2 and St. 4-5, while those for Chl-a, POC, PON and $\mathrm{C} / \mathrm{N}$ were derived from the comparison between St. 1 and 5. ND, no data. 


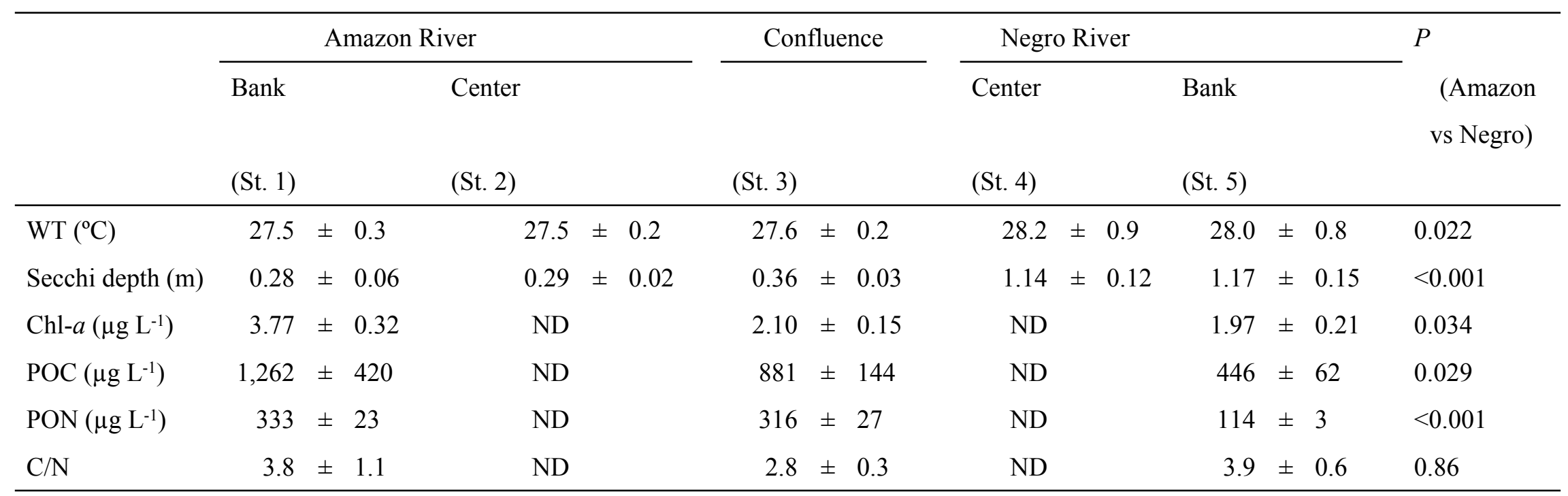




\section{Table 3(on next page)}

Spatial variation in the density of mesozooplankton

Average (mean $\pm \mathrm{SD}$ ) density (ind. $\mathrm{m}^{-3}$ ) of cladocerans, copepods, insect larvae and total mesozooplankton in the Amazon River (St. 1-2), the confluence (St. 3), and the Negro River (St. 4-5) in the center of the Amazon basin. $P$ values indicate the differences in the values between the Amazon Rivers (average of St. 1-2) and the Negro Rivers (average of St. 4-5) tested by Student's $t$-test. 


\begin{tabular}{|c|c|c|c|c|c|c|c|c|c|c|c|c|c|c|c|c|}
\hline & \multicolumn{6}{|c|}{ Amazon River (white water) } & \multicolumn{3}{|c|}{ Confluence } & \multicolumn{6}{|c|}{ Negro River (black water) } & $\begin{array}{l}\text { P } \\
\text { (Amazon } \\
\text { vs Negro) }\end{array}$ \\
\hline Cladocerans & 834 & \pm & 250 & 414 & \pm & 266 & 1,363 & \pm & 635 & 1,924 & \pm & 886 & 1,999 & \pm & 947 & $<0.001$ \\
\hline Total & 1,291 & \pm & 271 & 627 & \pm & 366 & 2,228 & \pm & 1,388 & 2,975 & \pm & 1,232 & 2,484 & \pm & 1,068 & $<0.001$ \\
\hline
\end{tabular}




\section{Table 4 (on next page)}

Spatial variation in the biomass of mesozooplankton

Average (mean $\pm \mathrm{SD}$ ) biomass (mg dry weight $\mathrm{m}^{-3}$ ) of cladocerans, copepods, insect larvae and total mesozooplankton in the Amazon River (St. 1-2), the confluence (St. 3), and the Negro River (St. 4-5) in the center of the Amazon basin. $P$ values indicate the differences in the values between the Amazon Rivers (average of St. 1-2) and the Negro Rivers (average of St. 4-5) tested by Student's t-test. 


\begin{tabular}{|c|c|c|c|c|c|c|c|c|c|c|c|c|c|c|c|c|}
\hline & \multicolumn{6}{|c|}{ Amazon River (white water) } & \multicolumn{3}{|c|}{ Confluence } & \multicolumn{6}{|c|}{ Negro River (black water) } & $\begin{array}{l}\text { P } \\
\text { (Amazon } \\
\text { vs Negro) }\end{array}$ \\
\hline Cladocerans & 0.49 & \pm & 0.15 & 0.24 & \pm & 0.16 & 0.63 & \pm & 0.25 & 0.90 & \pm & 0.45 & 0.94 & \pm & 0.43 & $<0.001$ \\
\hline Total & 3.41 & \pm & 1.01 & 1.30 & \pm & 0.46 & 4.70 & \pm & 3.28 & 5.14 & \pm & 2.55 & 4.49 & \pm & 2.02 & 0.0034 \\
\hline
\end{tabular}

